\title{
3つの判定方法による結果の比較分析・ 福岡県下公営住宅におけるケーススタディ
}

\author{
「居住水準」判定に関する調査研究
}

\section{1.はじめに}

居住水準，住居水準あるいは住宅基準に関する既往研 究をみる時まず取り上げられるのは，昭和 16 年に日本 建築学会住宅問題委員会がまとめた「庶民住宅の技術的 研究」”であろう。この「1. 規模について」では一定の 就寝条件を設定し, 家族構成と室構成の関係を示してい る。これに対し批判的立場から西山外三らは昭和 17 年 「住宅設計基準と規格平面に就いて」う2) 発表している。 これらはいずれも住宅の計画的建設に当たり一つの基準 を示したものであり，国民全体の規範的住宅基準を示し たものではなかった。

一方, 当時国民の居住水準棌)の実態把握の指標とし て国勢調査では昭和 5 年に室数が, 昭和 16 年の「大都 市住宅調査」では室数, 疊数, 延面積が調查され, 戦後 は，昭和 23 年の第 1 回住宅調查結果報告で畳数が示さ れ, 昭和 28 年の住宅統計調查結果報告(以下住調と記す) からは室数が追加された。昭和 26 年に前川喜寛は，当 時の極端な住宅不足を背景に，「住居水準の最も直接的 な比較は 1 人当たり畳数である」き21 とし前述の「大都市 住宅調査」，と昭和 23 年住調結果の 1 . 人当たり畳数を比 較し居住水準の低下を指摘している。また三輪 恒も「さ しあたって，(中略）「1 人当居住面積」を中心とした「住 宅の居住性」(中略) あたりが住居水準を論ずる焦点と なってよいであろう」ぎ3) と述へてており，当時の諸状況下 では居住水準の実態把握指標として，1 人当たり畳数が 現実的だったのであろう。その後，三輪は住宅水準の指 標に関する研究で, 住宅の規模分布を取り上げ, 平均畳 数と平均延面積の関係を分析し，さらに「平均値を中心 とする分析だけでは不十分で, 分布の型」せ4)についても 検討を進めている。

その後, 昭和 42 年には居住水準に関する提案がなさ れている。いわゆる「本城提案」师5)といわれるもので, 建設基準としてではなく「一般的な目標としての水 準」表6)で，一定の就寝条件等を設け，世帯人員に応じて

本報告の一部は既に昭和 60 年の大会において（参考文献 24）発表して いる。

* 福岡大学 助手

(1988 年 9 月 7 日原稿受理, 1989 年 9 月 5 日採用決定)

\section{正会員飯田利彦*}

室構成，住戸専有面積を設定している。この提案に基づ

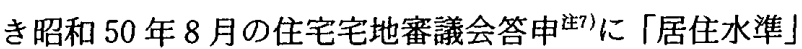
が設定され；第 3 期住宅建設五䇢年計画（以下， 3 期計 画と記す）に織り込まれ，第 4 期計画においても継承さ れているが，その特徵を規模条件についてみると，「年齢， 性別, 続柄を考慮した世帯構成」が必要とする「部屋ご との規模と部屋数」を設定したことであり, 昭和 40 年 代の住宅政策の目標であった「一世帯一住宅」,「一人一 室」という流れのなかで「一室の規模」を条件として設 定したことは，住宅政策史上大きな意義があるといえよ う。その後, 昭和 53 年, 昭和 58 年の住調および住宅需 要実態調査結果報告（以下，住需調と記す）では，それ までの「狭小過密」に替わる新たな指標が設けられ，居 住水準状況と表して最低, 平均の項目で揭載されている。 そして, 昭和 55 年 7 月, および昭和 60 年 6 月の住宅宅 地審議会答申范8 2 では 3 期計画設定の「居住水準」の達 成状況を住調に基づき述べている。

さて，住宅政策の目標水準として設定された「居住水 準」は，同時に政策の効果を測定するための基準尺度， すなわち実態把握尺度としての機能も求められる。しか し，3 期計画の「居住水準」と住調, 住需調で使用され た尺度は，住戸規模にかぎっても同じとは言い難い内容 である。すなわち，目標尺度と実態把握尺度が異なって いるのである。住調, 住需調はいずれも全国レベルでの 実態調査であり，「居住水準」で設定された規模基準を 適用するには，対象住戸すべての間取りの採集が必要と なり, 大量調查では不可能に近いことであろう。したがっ て, 実際の計量においては, 簡便な方法が使用されたも のと思われる。しかし, 目標尺度である「居住水準」と, 簡便な方法が使用された実態把握尺度との違いを，同一 視する混乱は避けねばならない。したがって本論では， この違いに着目し，3期計画「居住水準」の規模基準お よび設備基準による計量結果と, 住調, 住需調で使用さ れた尺度による計量結果の違いが，どのように異なって 現れるかを検討目的とした。

その方法として第 3 期計画設定の「居住水準」の内容 と，2つの全国調查（住調, 住需調）の判定方法および 
調査結果を比較検討し，さらに特定の住宅集団を取り上 げ，そこに住む世帯構成と空間構成との関係を実態調查 を通じて分析し，「居住水準」に沿った判定方法，およ び住調，住需調の判定方法による判定結果の違いを検討 していく。特に「居住水準」に沿った判定方法では，そ の大きな特徵である「一室の規模」条件も考虑し「居住 水準」の判定を試みている。

全国レベルの統計資料を用いて住宅事情を測る方法の 研究としては前述の三輪のほか，玉置伸俉ら ${ }^{7}$ や渡辺光 雄ら ${ }^{81,99}$ の研究がある。このうち，玉置らは室数と世帯 人員との関係から余剩室数分布を考察しているが，これ に対し，本論では約 1 万 8 千世帯の実態調查に基づき， 各住戸の「一室の規模」を検討し，その結果を「居住水 準」の判定に加味していることが特徵といえよう。

\section{2. $2 つ の$ 全国調查，「住宅統計調查」と「住宅需要実} 態調査」の比較

昭和 53 年, 58 年に行われた住調および住需調に「居 住水準」の判定結果が「最低水準」「平均水準」の項目 で揭載されている。これらの結果報告の解説によれば, 住調では, 「第四期住宅建設五䇢年計画では1)居住室 (寝 室，食事室等)，(2)設備（便所，洗面所等)，(3)住宅の環 境 ${ }^{* 10}$, (4)世帯人員別住宅規模（室構成，居住室面積，

住戸専用面積，住宅総面積）の四つの基準で最低・平均 居住水準を設定しているが，このうち(1)居住室，(4)世帯 人員別住宅規模の居住室面積（疊数）の二つの基準を用 いた」゙"11) とし，住需調では「家族構成と居住室疊数の 関係」望 ${ }^{122}$ で区分したとしているが，両報告書とも，よ り詳細な判定内容については触れていない。

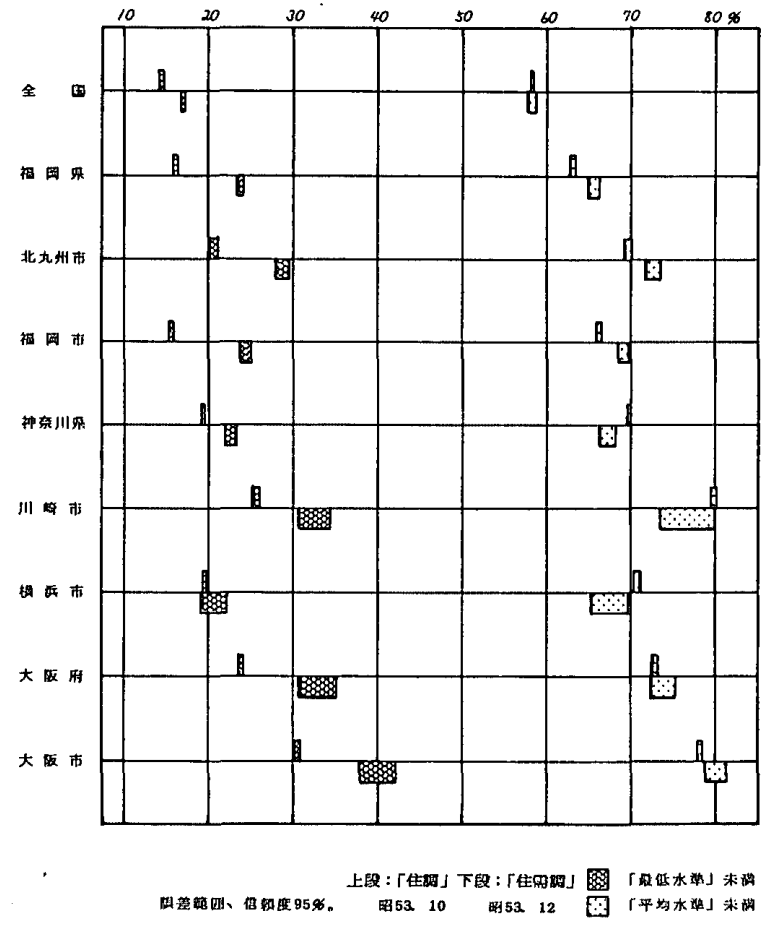

図一1「居住水準」未満世帯構成比比較
昭和 53 年, 58 年の両調査は, 10 月と 12 月でわずか 2 力月のズレで行われ，ともに抽出調查である。昭和 58 年調查でみると住調が約 $1 / 10 \sim 1 / 12$ の世帯を抽出し ているのに対し，住需調はそれより $1 / 30$ 倍程少なく，

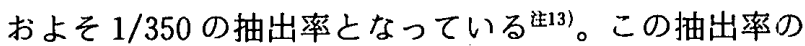
違いは，推計値の誤差範囲の大きさの違いとなって見れ る。図一 1 は入手し得た昭和 53 年住需調の国, 大阪府, ほか 8 府・県 ${ }^{\sharp 4)}$ ・市のうち, 誤差範囲を明記した主な 地域について，住調と「居住水準」の調查結果を比較し たものである。信頼度 $95 \%$ の誤差範囲を考慮しても違 いがみられ，特に「最低水準」未満世帯の構成比におい て違いが著しく，住調結果より住需調の結果が示す「最 低水準」未満世帯構成比が，全国レベルで約 $2 \%$ ，府・ 県・市レベルで $10 \%$ ほど高い。このうち，大阪府では 住需調でも所有関係別に調查結果が揭載されており，大 阪市について $2 つ の$ 調查結果の比較を図一 2 に示す。「最 低水準」未満世帯構成比は，いずれの所有関係において も住需調結果が高い。また，大阪府レベルにおいても同 様の結果であった。前述したように詳細な判定内容は不 明であるが，住調では「居住室」についての条件が加味 されており，住需調より厳しく判定されているように思 われるが，結果は逆に現れている。

昭和 58 年住需調報告書が入手できた全国，16 都府 県世15) および北九州市, 福岡市について, 昭和 53 年調 查の場合と同様に住調と住需調の「最低水準」未満世帯 構成比の差を比較検討したが，昭和 53 年調査の場合に 比べその差は大幅に縮まり，都府県および市レベルの全 体で約 $2 \%$, 所有関係別にみても約 $5 \%$ 程となってい る。

他方，両調查結果は，所有関係別構成比率に大きな違 いがみられ，昭和 53 年，58 年ともに，住調に対し住需 調の方が，「民営借家」が少なく「持ち家」が多い傾向 がみられる。これは，「持ち家」の「居住水準」が一般 に高いことを考慮すれば，「持ち家」の構成比率が多い

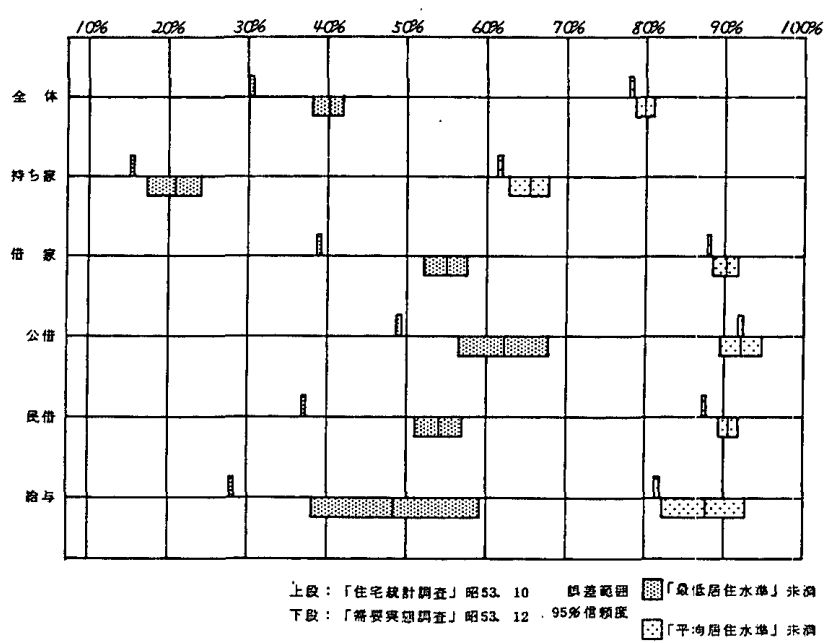

図一2「居住水準」未満世帯構成比 比較・所有関係洌，大际市 
住需調の方が「全体」の「居住水準」未満世帯構成比は 低く現れると思われるが結果は逆である。

では，このようなことがよ゙のような事情で起こるので あろうか？。その主なものとして次の 3 つのことが考え られよう。

[1] 調査対象の抽出方法による違い。

[2] 調査内容による違い。

［3］資料の集計・整理方法による違い。 である。［1] に関することのうち，抽出率については 前述したように，統計的には誤差範囲の問題に帰せられ よう。また [2] に関しては, 調查票および報告書の解 説等から読みとれる範囲では，次のことを除いては，見 当たらない。それは昭和 53 年調査における同居世帯の ある主世帯の取り扱いである。住調においては「同居世 帯が使用している室も居住室として含めるのに対し，住 需調では除かれた資料となっている。すなわち，住需調 より住調の方が，同居世帯のいる主世帯の総畳数は多く 現れ，「居住水準」未満世帯は少なく現れることになる。 しかし同居世帯の総世帯に占める割合は 11 大都市レベ ルや全国人口集中地区レベルで $1 \%$ 前後であり, 前述 のズレに大きく関係しているとは思われない。したがっ

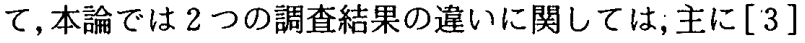
の「資料の集計・整理方法による違い」にかかわる点に ついての検討を試みるものである。

\section{3. 調査対象および分析対象の概要}

今回の検討対象は，福岡県営住宅および北九州，福岡 両市営住宅のうち長期経過の住宅である。一般に長期経 過の公営住宅は「居住水準」の低さが指摘され，建替え

表-1 調查別分析対象団地数・住戸数等一覧表

\begin{tabular}{|c|c|c|c|c|c|c|}
\hline 錭查名 & 管理綒数 & 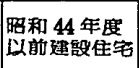 & 調查对像 & 分析就媱 & 的查查時期 & $\begin{array}{l}\text { 借 考 } \\
\text { (强枓時期) }\end{array}$ \\
\hline 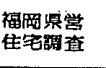 & $201^{* 1}$ & $\begin{array}{r}165 \\
9,309\end{array}$ & $\begin{array}{r}162 \\
9,041\end{array}$ & $\begin{array}{r}162 \\
7,557\end{array}$ & 昭和 59 年 5 月 & 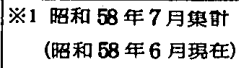 \\
\hline $\begin{array}{l}\text { 北九州市営 } \\
\text { 住宅謂盁 }\end{array}$ & $388^{\circledast 2}$ & $\begin{array}{r}129 \\
10,173\end{array}$ & $\begin{array}{r}78 \\
7,555\end{array}$ & $\begin{array}{r}64 \\
5,745\end{array}$ & 昭和 61 年 7 月 & 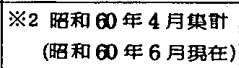 \\
\hline 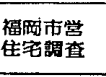 & $\begin{array}{r}148^{* 3} \\
27,321\end{array}$ & 46 \%4 & $\begin{array}{r}21 \\
5,162 \\
\end{array}$ & $\begin{array}{r}18 \\
4,295\end{array}$ & 昭和 61 年 5 月 & 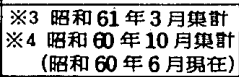 \\
\hline
\end{tabular}

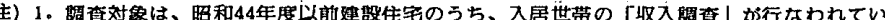

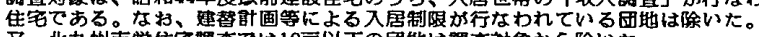

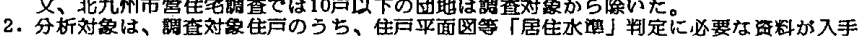
でた住戸である

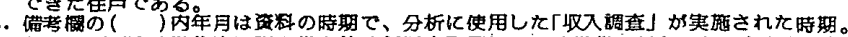

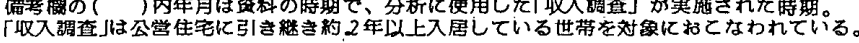

や 2 戸を 1 戸に改造する「2戸1」等の住戸改善等が進 められてきている。

ここで, 昭和 58 年住調結果を使用し, 公営住宅の「最 低居住水準」状況を概観し，検討対象の位置付けを行っ ておこうき16)。住調結果によれば，福岡県下の「最低居 住水準」未満世帯構成比は $29.4 \%$ で, 全国レベルの $35.3 \%$ より若干少なく, また, 全国人口集中地区の $36.7 \%, 11$ 大都市全体での $37.5 \%$ に対し, 北九州市 は $26.2 \%$ ，福岡市は $28.0 \%$ と比較的水準が高い。し かし, 長期経過（昭和 45 年以前建設）の公営住宅に限つ た場合，福岡県下は $45.2 \%$ で，全国レベルの $48.2 \%$ と差がなく，全国人口集中地区の $48.2 \% ， 11$ 大都市全 体での $50.7 \%$ に対し，福岡市は $50.7 \%$ とほとんど同 じであり, 北九州市は $42.8 \%$ で若干水準は高いものの 大きな開きは見られない。さらに,これらの地域におけ る公営住宅の 1 住宅当たりの平均畳数, および平均世帯 人員を比較しても大差はなく，したがって，今回調查対 象とした公営住宅が，ほかの地域の公営住宅に比較し， 特異な状況下のものではないと考えられる。

調査は表-1 に示すように 3 回に分けて行った。調查 対象は，昭和 44 年度以前建設住宅のうち，入居世帯の 比較的現在に近い世帯構成がわかる「収入調查」洋17) が 行われている住宅とした。なお，建替え済み，ならびに

表一2 管理主体別, 構法・構造別, 呼称住戸型別, 住戸数内訳

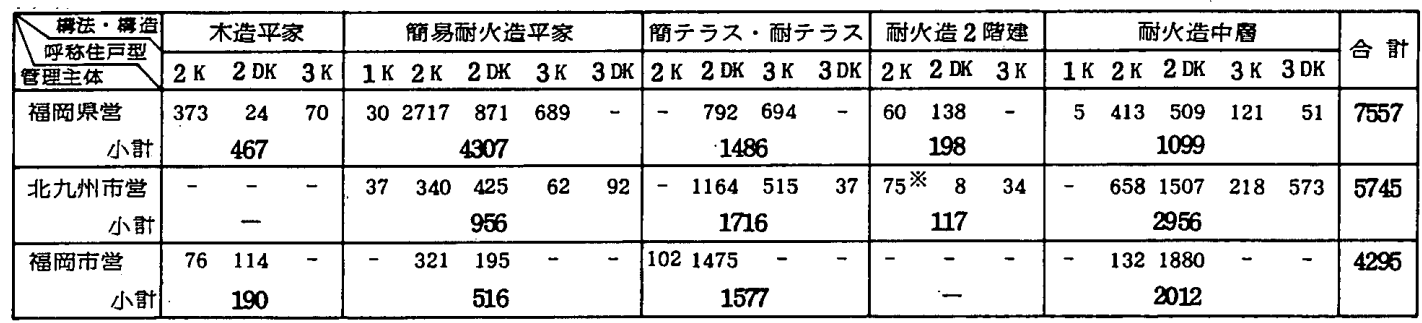

※閔易耐火造 2 陵建7戸を含む。

注）简テラス：簡易耐火造テラス。耐テラス：耐火造テラス。

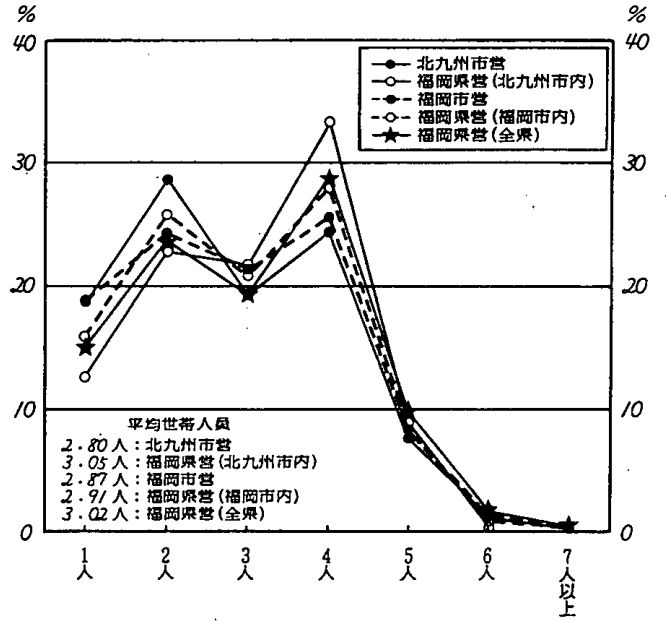

図-3 世帯人員別世帯分布比較, 北九州市営・福岡 県営 (北九州市内) - 福岡市営 $\cdot$ 福岡県営 (福 岡市内) ・ 福岡県営 (全県) 


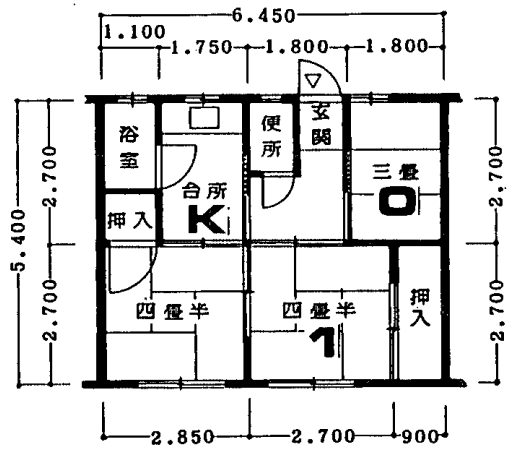

A 専有面程 : $34.83 \mathrm{~m}^{2}$

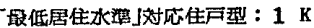
$\mathrm{S} 38,39$ 建設 㙕网県四称住戸型 : $3 \mathrm{~K}$
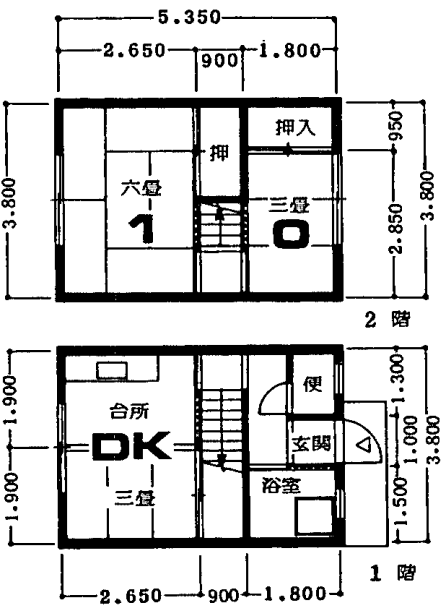

E 西直面程: $40.66 \mathrm{~m}^{2}$

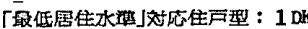

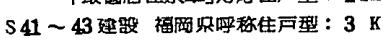

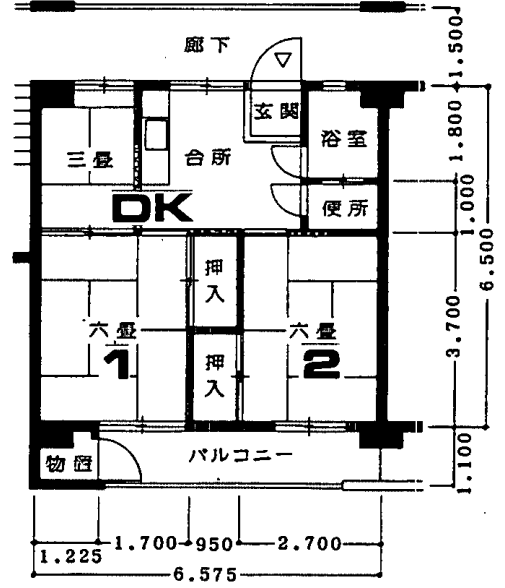

C 専有面和 : $44.08 \mathrm{~m}^{2}$

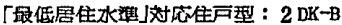
$S 42,43$ 建設福岡宗呼称住户型： $3 \mathrm{DK}$

図一4 住戸平面図・福岡県営 - 呼称住戸型 $3 \mathrm{~K}, 3 \mathrm{DK}$ 。

建替え計画等で入居制限が行われている団地は除いた。 また，北九州市営住宅調查では，10 戸以下の小規模団 地も除いている。分析対象は，この調查対象住戸のうち， 住戸平面図等「居住水準」の判定に必要な資料が入手で きた住宅であり, 福岡県営は 7,557 戸(昭和 44 年度以 前建設住戸の約 $81 \%$ ), 北九州市営は 5,745 戸（同じく 約 $57 \%$ ), 福岡市営では 4,295 戸(同じく約 $66 \%$ )であっ た。使用した基礎資料は, 各管理主体の基本管理台帳む18), 収入調査票，および住戸平面図から一定の調查項目を転 写したものである。基礎資料転写作業の都合で，資料時 期が福岡県とほかの 2 市とは 2 年間のズレがあるが，今 回の検討目的に照らし，大きな問題はないと考える。

表一2 は, 管理主体別に構法・構造別, 呼称住戸型の 内訳戸数を，また，図一3は同じく世帯人員別構成比を 示した（福岡県営は北九州市内と福岡市内を別揭した）。 福岡県営では簡易耐火造平家が半数以上を占めるのに対 し, 両市営では耐火造中層が半数近くを占めている。呼 称住戸型では，いずれの管理主体においても $2 \mathrm{~K}$ 型と $2 \mathrm{DK}$ 型で大半を占めているが, 福岡県営では $2 \mathrm{~K} か ゙$, 両市営では $2 \mathrm{DK}$ が多い構成となっている。平均世帯人 員は (図一 3 参照), 北九州市営の 2.80 人から福岡県営 · 北九州市内の 3.05 人までとあまり大きな開きはない。

表一3「居住水準」判定ケースの内容

\begin{tabular}{|c|c|c|c|}
\hline ケース & 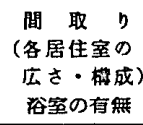 & 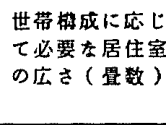 & 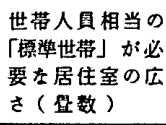 \\
\hline ケース 1 & & & \\
\hline ヶ & & & \\
\hline ケース 3 & & & \\
\hline
\end{tabular}

世帯人員は， 4 人， 2 人の世帯が多く, 5 人以上はごく わずかとなる。世帯構成は，いずれの管理主体において も「夫婦十子」が約半数を占め,「単身」「「夫婦」「片 親十子」がそれぞれ 10〜20\%を占める構成となってい る。

\section{4. 「居住水準」判定の方法}

3 期計画で設定されている「居住水準」の内容と, 住 調および住需調の「居住水準」に関する解説を踏まえ， 表一3に示すような 3 つのケースで「水準」判定を行い, 判定方法の違いによる結果の相違について検討を試み る。

ケース1.これは, 住戸の間取り, および浴室の有無 と, 世帯構成に応じて必要とされる居住室の広さ(轠数) に基づく判定である。住戸の間取りとは 3 期計画設定「居 住水準」の「居住室について」にかかわるもので, 例え ば「最低居住水準」の内容は, 2 人以上 4 人以下の世帯 が居住する場合, $7.5 \mathrm{~m}^{2}$ (4.5 畳) 以上の DK（食事兼 台所）が必要であり, また, 夫婦の寝室は $10 \mathrm{~m}^{2}$ (6 畕), 最も狭い居住室でも $7.5 \mathrm{~m}^{2}$ (4.5 䟧) 必要とされている。

表一4「最低居住水準」対応住戸型別, 呼称住戸型别, 浴室の 有無別住戸数 - 構法 ·構造別

: 昭和 60 年 6 月現在 福岡市営住宅・昭和 44 年度以前建設 昭和 58 年 9 月以前入居

\begin{tabular}{|c|c|c|c|c|c|c|c|c|c|}
\hline 对不住戸型 & \multicolumn{3}{|c|}{$1 \mathrm{~K}$} & \multicolumn{2}{|c|}{$10 \mathrm{~K}$} & \multicolumn{2}{|c|}{$2 D K-A$} & $20 K-\theta$ & \multirow{3}{*}{ 合政 } \\
\hline 四称住严型 & \multicolumn{2}{|c|}{$2 \mathrm{~K}$} & $20 \mathrm{DK}$ & $2 \mathrm{k}$ & $2 \mathrm{DK}$ & $2 \mathrm{~K}$ & $20 \mathrm{~K}$ & $2 \mathrm{~K}$ & \\
\hline 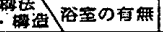 & 刑 & 福 & 直 & 百 & 醉 & 有 & 直 & 有 & \\
\hline 木浩 & - & 76 & 1 & - & 39 & - & 74 & - & 190 \\
\hline 間酎 - 平溷 & - & 294 & 164 & 27 & - & - & 31 & - & 516 \\
\hline 网酎・テラス & - & 20 & 419 & 82 & 1056 & - & - & - & 1577 \\
\hline 酎火 - 中团 & 14 & 80 & 538 & - & 11 & 17 & 1331 & 21 & 2012 \\
\hline 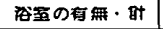 & 14 & 470 & & & & & & & \\
\hline 吗杵住戸型 - 旪 & & & 1122 & 109 & 1106 & 17 & 1436 & & \\
\hline 对五住戸型 - 时 & \multicolumn{3}{|c|}{1606} & \multicolumn{2}{|c|}{1215} & \multicolumn{2}{|c|}{1453} & 21 & $429: 5$ \\
\hline
\end{tabular}

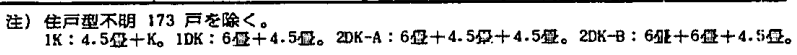




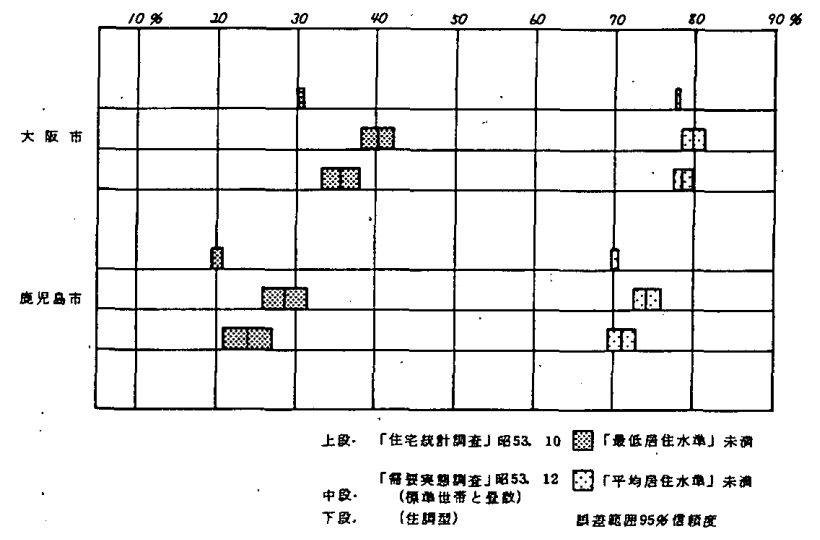

図一个居住水準」未満世帯構成比比較

したがって，例えば福岡県営住宅に事例をとると，図一 4 の A は呼称住宅型では $3 \mathrm{~K}$ であるが, 3 期計画設定の 「居住水準」に基づけば， 3 畳の部屋は居住室として認 められず，また $\mathrm{K} は 4$ 畳半未満のため，隣接する 4 畳半 を併せて DK とし, 残りの 4 畳半を居住室として $1 \mathrm{DK}$ として扱うことになる。しかし 3 期計画設定の $1 \mathrm{DK} の$ 1 個室は 6 畳であり，これより小規模住戸型は単身者向 けの $1 \mathrm{~K}$ 以外にない。よって $1 \mathrm{~K}$ 型と読み换えざるを 得ない茫19)。同様に B の県呼称テラスの $3 \mathrm{~K}$ 型も，Cの 中層耐火造の $3 \mathrm{DK}$ 型も, それぞれ $1 \mathrm{DK}$ 型, $2 \mathrm{DK}$ - $\mathrm{B}$ 型（表一4の注参照）となる。このように 3 期計画設定 の「最低居住水準」の内容に沿って住戸型を分類整理し た住戸型を「最低居住水準」対応住戸型とする。（以下， 対応住戸型と略記。なお特記なき場合は呼称住戸型を意 味する) また，「最低水準」の設定では，2 人以上の世 帯には専用の浴室を確保することとされている。表一4 は，今回分析対象の福岡市営住宅について，対応住戸型 と呼称住戸型および浴室の有無の関係を整理したもので あるが，全体の約 $85 \%$ を占める $2 \mathrm{DK}$ 型の内，対応住 戸型では $1 \mathrm{DK}$ と読み替えざるを得なかった住戸が約 $30 \%$ ，また，対応住戸型 $1 \mathrm{~K}$ と読み替えざるを得なかっ た住戸が約 $31 \%$.であった。北九州市営, 福岡県営につ いても同様の割合をみると, $2 \mathrm{DK}$ を対応住戸型 $1 \mathrm{DK}$ と読み替えたのが各々約 $57 \%$, 約 $43 \%, 1 \mathrm{~K}$ 之読み替 えたのが各々約 $20 \%$, 約 $45 \%$ であった。以上のように, 同じ呼称住戸型でも部屋同士の組み合わせによっては, 異なる「居住水準」対応住戸型に読み替えることになり， このような読み替えは 3 期計画設定の「居住水準」に基 づく判定を行おうとする時，見落とすことのできない重 要な条件である。しかし，このように住戸型の読み替え を行うためには，調査対象すべての住戸について，間取 りの調查が要件となってくる。

ケース2．間取り，および浴室条件を考虑せず，居住 する世帯の世帯構成（年㱓, 性別, 続柄) に応じて必要 な居住室の総畳数での判定。(住調の判定方法は, その 解説等から,このケース 2 の方法に相当。)
表一5 部屋レベル「最低居住水準」設定值 適, 不適内訳

\begin{tabular}{|c|c|c|c|c|c|c|c|}
\hline 管理主体別 & 項目 & $1 \mathrm{~K}$ & $2 K$ & $2 \mathrm{DK}$ & $3 k$ & 3 DK & 合 计 \\
\hline \multirow{6}{*}{$\begin{array}{l}\text { 北九州市 } \\
\text { 市営住軍 }\end{array}$} & 积戸数 & 65 & 1326 & 3634 & 950 & 802 & 6777 \\
\hline & $\Delta 1$ & 65 & 257 & 85 & 0 & 0 & 407 \\
\hline & $A 2$ & 65 & 354 & 85 & 0 & 0 & 504 \\
\hline & $E$ & 0 & 484 & 600 & 385 & 754 & 2223 \\
\hline & $\mathbf{C}$ & - & - & 1236 & - & 0 & 1236 \\
\hline & $\boldsymbol{D}$ & 0 & 488 & 1713 & 565 & 48 & 2814 \\
\hline \multirow{6}{*}{$\begin{array}{l}\text { 福岡市 } \\
\text { 市営住宅 }\end{array}$} & 短宁数 & - & 714 & 4230 & - & - & 4944 \\
\hline & A1 & - & 141 & 663 & - & - & 804 \\
\hline & $A \geq$ & - & 471 & 663 & - & - & 1134 \\
\hline & $\boldsymbol{E}$ & - & 216 & 91 & - & - & 307 \\
\hline & $\mathbf{c}$ & - & - & 2412 & - & - & 2412 \\
\hline & $\boldsymbol{D}$ & - & 27 & 1064 & - & - & 1091 \\
\hline
\end{tabular}

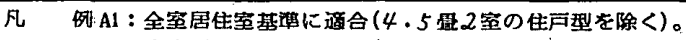

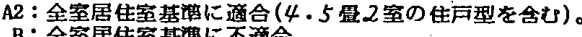
B : 全室居住室基愺に不適合。 C：DKを除く全居住空、交通合。 $\mathrm{D}:$ : 他 (紷戸数 $=A 2+B+C+D)$

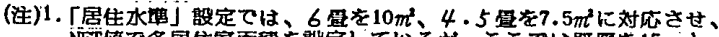
NET值で各居住室面程を設定しているが、ここでは䇒原を15 cm

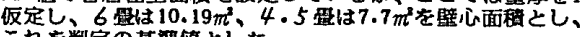
これを判定の基帮值とした。

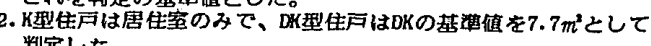
判定した。

3. 住戸型は、呼称住戸型である。

4.この内訳戸数は、居住年数が 2 年末佩のため「収入調查」の对象に ならなかった世蒂の住月を含し。

ケース3.これは，ケース1，ケース 2 で用いた，そ こに居住する世帯の世帯構成ではなく，その世帯人員相 当の「標準世帯」せ20)に必要な居住室の総畳数に基づく 判定である。これは, 昭和 53 年住需調で入手できたも ののうち, 大阪府, 愛知県, 鹿児島県, 沖縄県の報告書 で,「居住水準」に関する集計を，同一地域について「標 準世帯と毘数」と「住調型」という二つの表題で, 別々 に集計結果が掦載されていたことによる。このうち大阪 市と鹿児島市の場合について, 二つの集計結果と, 住調 の結果とを比較して示したのが図一5であるが，いずれ の都市においても住需調の「住調型」結果の方が, 住調 の結果に近い構成比となっている。

ところで，3期計画設定の「居住水準」では，前述し たように，居住室の広さを例えば， $10 \mathrm{~m}^{2}$ を 6 畳に， $7.5 \mathrm{~m}^{2}$ を 4.5 畳に対応させ設定している。これは, 昭 和 42 年 12 月の住宅対策審議会 (住宅宅地審議会の前身) の基本問題部会による「適正な居住水準についての中間 報告」æ211 の中で，居住室の広さを $90 \mathrm{~cm}$ をモデュール としたネット面積で設定し, 各々 $9.72 \mathrm{~m}^{2}, 7.29 \mathrm{~m}^{2}$ と していたものを㹡大側にラウンド・ナンバー化し，それ を 6 胃, 4.5 畳と換算した結果によるものと思われるが, 今回対象の公営住宅では図一4 の住戸平面でもわかるよ うに，いわゆる「寸づまり」の部屋が多い泣22)。表一5は， 両市営住宅について, 部屋レベルの広さを検討したもの である。ここでは， $90 \mathrm{~cm}$ モデュールのネット面積に， 壁厚を $15 \mathrm{~cm}$ (片側のみ) と仮定し，6 畳は $10.19 \mathrm{~m}^{2}$, 4.5 畳は $7.7 \mathrm{~m}^{2}$ を壁心面積（グロス面積）として判定 の基準値とした。なお，K（台所）は，居住室に含まれ ないため考慮していない。表一 5 からわかるように，全 
室基準値に適合するものは (A 1)，北九州市営はわず か約 $6 \%$, 福岡市営でも約 $16 \%$ と少なく, 4.5 畳 2 室 の住戸型を含めても (A 2), それぞれ約 7\%,23\%で ある。これらの条件も，3 期計画設定の「居住水準」の 内容を忠実に判定条件とした場合, 加味されるべき内容 であるが, 以上のような状況であるため, 今回の判定条 件には含めていない。このように, 畳 6 枚敷いてあれば ネット面積にかかわらず 6 畳と判定する場合を「畳数判 定」，モデュール寸法を基準にしたネット面積で判定す る場合を「面積判定」とし，区別している。

また， 3 期計画設定の「平均居住水準」では, 主寝室 は $13 \mathrm{~m}^{2}$ (8 畳) としているが, 今回分析対象の住戸で 8 畳以上の居住室をもつものは皆無であった。したがっ

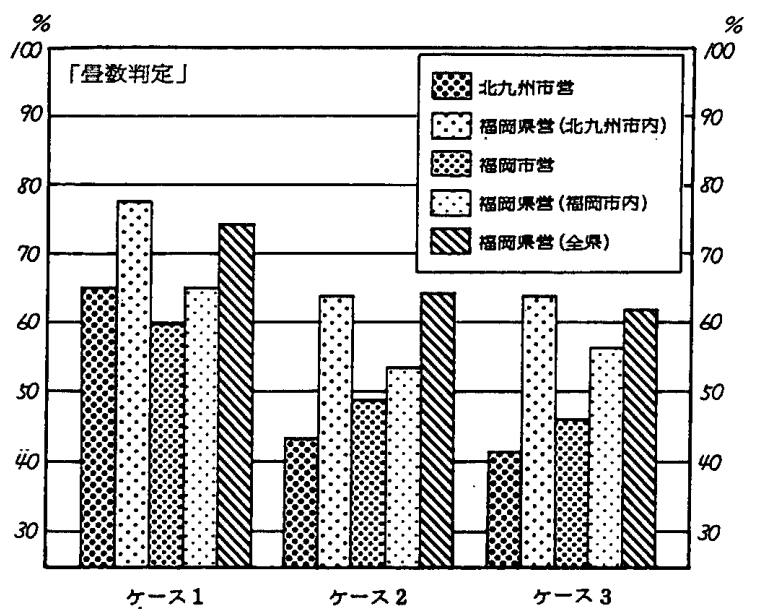

図一6「最低居住水準」未満世帯構成比比較, 北九州市営・福 岡県営 (北九州市内) - 福岡市営 - 福岡県営(福岡市内) 福岡県営 (全県)

北九州市営：昭和 60 年 6 月現在

昭和 44 年度以前建設 - 昭和 58 年 10 月以前 入居

福岡市営：昭和 60 年 6 月現在

昭和 44 年度以前建設 ·昭和 58 年 9 月以前入 居

福岡県営：昭和 58 年 6 月現在

昭和 44 年度以前建設 - 昭和 56 年 9 月以前入 居

表一6 浴室の有無内訳比較

北九州市営・福岡県営 (北九州市内) - 福岡市営 - 福岡 県営 (福岡市内) ・福岡県営 (全県)

\begin{tabular}{|c|c|c|c|c|}
\hline \multirow{2}{*}{ 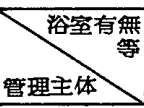 } & \multirow[b]{2}{*}{ 浴室有 } & \multicolumn{2}{|c|}{ 浴室無 } & \multirow[b]{2}{*}{ 合計 } \\
\hline & & 单身世帯 & 二人世带 & \\
\hline 北九州市嫦 & 4218 & 296 & 1095 & 5609 \\
\hline $\begin{array}{c}\text { 裀岡県棠 } \\
\text { (北九州市内) }\end{array}$ & 605 & 27 & 162 & 794 \\
\hline 裍同市棠 & 4123 & 9 & 5 & 4137 \\
\hline $\begin{array}{c}\text { 福岡柴営 } \\
\text { (禩岡市) }\end{array}$ & 622 & 27 & 140 & 789 \\
\hline 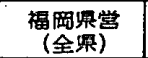 & 6482 & 104 & 650 & 7236 \\
\hline
\end{tabular}

注) 図 7の住戸で居住世帯の世帯構成が判明して

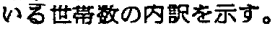

て, 今回の公営住宅では「最低居住水準」についてのみ 検討することとする。

\section{5. 「最低居住水準」判定の結果}

ケースごとに管理主体の「最低居住水準」未満世帯構 成比を図一6に示す。いずれの管理主体においてもケー ス 1 の場合が「最低水準」未満世帯構成比が最も高く, 約 60 〜 $80 \%$ を占める。ケース 1 の判定で使用した「最 低居住水準」対応住戸型の構成比を図一7に示したが, 「夫婦十子供 1 人」の 3 人世帯が「最低水準」をクリアー する対応住戸型の $2 \mathrm{DK}-\mathrm{A}$ 以上が少なく, かつ平均世 帯人員も 3 人を超える福岡県営 - 北九州市内と福岡県 営・全県は「最低水準」未満世帯構成比がそれぞれ, 78 $\%, 73 \%$ と比較的高い。逆に, 対応住戸型の $2 \mathrm{DK}-\mathrm{A}$ 以上が比較的多く, かつ平均世帯人員も 3 人以下の福岡 市営は「最低水準」未満世帯構成比が $60 \%$ で最も低い。

次にケース 1 とケース 2 の結果の違いをみると, 北九 州市営を除く管理主体においてはケース 1 よりケース 2 の方が「最低水準」末満世帯構成比が約 10 14\% 低く なり, 北九州市営の場合, 約 $22 \%$ も低い結果となった。 ケース 2 では, 浴室条件が無視されることと, 4.5 盢末 満の居住室の畳数が復活加算されるため, 一般に「最低 水準」末満世帯構成比は低くなる。それにしても, 北九

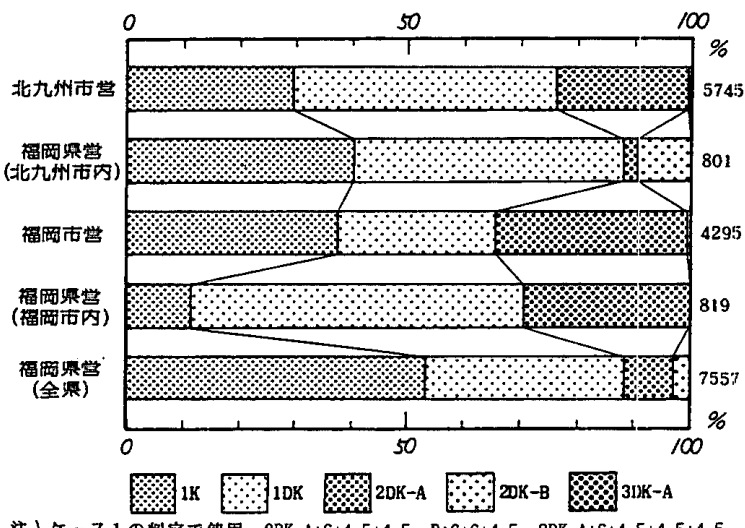

注) ケース1の判定で便用. $2 D K-A: 6+4.5+4.5 ， B: 6+6+4.5,3 D K-A: 6+4.5+4.5+4.5$

図一7「最低居住水準」対応住戸型別住戸数構成比比較, 北九 州市営・福岡県営 (北九州市内) - 福岡市営 $\cdot$ 福岡県営 (福岡市内) · 福岡県営 (全県)

表一7「最低居住水準」判定におけるケース別必要晅数の比較

\begin{tabular}{|c|c|c|c|c|}
\hline 世带歌 & \multicolumn{2}{|c|}{ 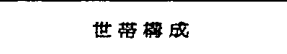 } & ケース. 2 & ケース. \\
\hline \multirow{3}{*}{2 人 } & 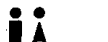 & （夫蛡） & 10.5 冝 & \multirow{3}{*}{10.5 但 } \\
\hline & & 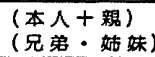 & \multirow{2}{*}{15 骨 } & \\
\hline & 88 & $($ 本人十子) & & \\
\hline \multirow{3}{*}{41} & 188 & （夫姆十子） & 15 営 & \multirow{3}{*}{19.5 但 } \\
\hline & i\&\&8 & （夫㚼十子） & 16.5 & \\
\hline & ¿i昌8 & (夫姆 +子) & 19.5 & \\
\hline 凡心 & 8 & 8オよ上) & \multicolumn{2}{|c|}{ 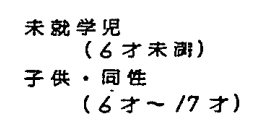 } \\
\hline
\end{tabular}


州市営の場合，このように約 $22 \%$ と大きく低下したの は，表一6に示すように， 2 人以上の世帯で浴室のない 住戸に居住する世帯が全体の約 $20 \%$ を占めていたこ と,また，図一7の「最低居住水準」対応住戸型の構成 比は福岡市営等と大差はみられないものの, 4.5 畳未満 の居住室がある住戸が，福岡市営では全体の約 $37 \%$, 福岡県営・福岡市内は約 $27 \%$ であるのに対し, 北九州 市営の場合，半数近くの $43 \%$ を占めていたこと，さら に, 総畳数が 16.5 畳 (ケース 2 では「夫婦十子供 2 人 (同 性)」型世帯の「最低水準」を満たす）注33) 以上の住戸が 福岡市営は約 $2 \%$, 福岡県営・福岡市内は約 $1 \%$ に対 し, 北九州市営では約 $23 \%$ と比較的多い構成比となっ ていること等, これらのことが主な理由と考えられる。

さらにケース 2 とケース 3 の結果の違いをみると, 北 九州市営, 福岡市営, 福岡県営・全県は, 「最低水準」 未満世帯構成比がケース 2 よりケース 3 の方が 2 - $3 \%$ 減少し, 逆に, 福岡県営・福岡市内では, 構成比が約 $3 \%$ 高くなった。一方, 福岡県営・北九州市内では変 化がみられなかった。

ケース 2 とケース 3 で結果が異なってくる理由を, 表 -7 に世帯人数 2 人と 4 人の場合で示したが, ケース 3 では，世帯人数相当の「標準世帯」が居住しているもの とし, 2 人は「夫婦」で 10.5 畳, 4 人は「夫婦十子供 2 人 (同室就寝不可)」で 19.5 畳以上必要, として判定さ れるのに対し，ケース 2 では，実際に居住する世帯の構 成 (年歯, 性別, 続柄) で必要畳数を算定するため, ケ一 ス 3 より必要畳数が少なくなる世帯や，その逆の場合が ある。すなわち,ケース 2 とケース 3 での結果の違いは, 判定対象集団の世帯構成の分布状況で異なってくる。こ の間の事情は,「最低水準」の判定結果を, 公営住宅に 特有の第 1 種，第 2 種の区分で整理すると特徵的に現れ る。図一8は, 各管理主体について種別にそれぞれのケー スの判定結果を示したものであるが，福岡市営と福岡県 営・全県の場合，ともに第 1 種ではケース 2 よりケース 3 が「最低水準」末満世帯構成比が $5 \sim 6 \%$ 高く, 第 2

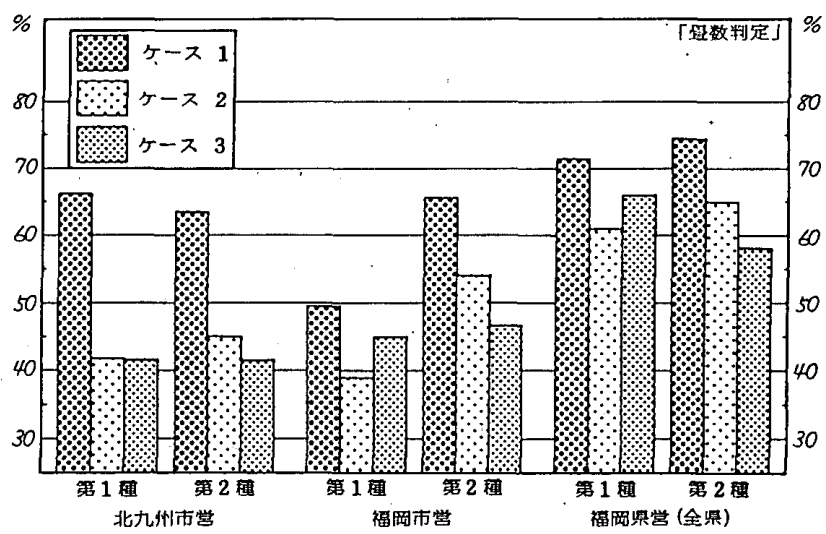

図一8「最低居住水準」未満世帯構成比比較・種別，北九州市 営・福岡市営・福岡県営 (全県)
種ではそれとは逆に 6〜7％ 低い結果よなっている。こ れは，両管理主体において第 1 種と第 2 種の世帯構成状 況に違いがあることが大きく関係している。両管理主体 の主な世帯構成型は, 第 1 種, 第 2 種ともに「夫婦十子」, 「夫婦」，「単身」，および「「片親十子」である。このうち 最も比率が高いのは両種とも「夫婦十子」であるが，そ の比率は第 1 種は福岡市営が約 $55 \%$, 福岡県営 : 全県 が約 $63 \%$ に対し，第 2 種では各々 $39 \% ， 41 \%$ と比較 的少ない。一方，「片親十子」は第 1 種では各々約 $10 \%$, 約 $9 \%$ に対し，第 2 種では各々約 $17 \%$ ，約 $16 \%$ と比 較的多い比率となっている。(「夫婦」および「単身」は, ケース 2 とケース 3 の「水準」判定結果は同一であり, ケース間の判定結果の違いには影響しない。）さて，「夫 婦十子」のうち，夫婦と同室就寝が認められる6 歳末満 のいる世帯や，同室就寝が認められる兄弟・姉妹（6～ 17 歳の同性）のいる世帯では，ケース 3 においては表 一7の 4 人世帯の場合にみるように「標準世帯」に置換 されることにより,ケース 3 の方が必要畳数が多くなる。 このような世帯が「夫婦十子」に占める比率は, 第 1 種 では福岡市営が約 $57 \%$, 福岡県営・全県が約 $55 \%$ に 対し，第 2 種では各々 $31 \% ， 40 \%$ と比較的少ない比率 となっている。このようにケース 2 よりケース 3 の方が 必要畳数が多くなる世帯が全世帯に占める比率は, 第 1 種では福岡市営, 福岡県営・全県とも約 $30 \%$ で,この うち居住住戸の畳数不足で「水準」以上から「水準」未 満に変化した世帯は，福岡県営・全県で約 $25 \%$, 福岡 市営では約 $41 \%$ もあった。これに対し，第 2 種では, 必要畳数が增加した世帯が両管理主体とも全世帯の約 $10 \%$ で，その約 $15 \%$ が「水準」以上から「水準」未 満に変化したに過ぎない。

一方，逆にケース 3 で必要畳数が減少する「夫婦のい ない世帯」の構成比が，第 1 種では福岡市営が約 $16 \%$, 福岡県営・全県が $12 \%$ であるのに対し; 第 2 種では, 各々約 $25 \%, 20 \%$ と比較的多い構成比であったことが， このように第 1 種と第 2 種で，ケース 2 とケース 3 の判 定結果の関係が異なって現れてきたものと思われる。他 方, 北九州市営の場合, 種別によるこのような逆転現象 はみられなかった。

さて, 表一 8 は, 北九州市の昭和 53 年, 58 年の「住 宅需要実態調查」の原資料を利用する機会を得たので， その資料を使いケース 2 とケース 3 の判定方法で「最低」 「平均」の両「居住水準」の判定を試みた結果と, 住需 調報告書とを比較したものである。原資料は回収票数で あり, 他方, 住需調報告書は推計值で表章されているた め, 水準」未満世帯の構成比率を比較してみる。昭和 53 年調査結果は，所有関係別には公表されておらず全 体での比較しかできないが，「平均水準」では，報告書 とケース 2, ケース 3 との差は, ともに $0.15 \%$ 程で違 
の経年変化等を分析している。これは「居住水準」の各 室規模の設定値を検討する要素として重要であろう。

10）第四期住宅建設五箇年計画以後, 住環境水準として別途 に設定されている。

11）総務庁統計局：日本の住宅，p. 647，昭和 61.6。

12）建設省住宅局：昭和 58 年・住宅需要実態調査結果報告 (統計表編)，p.14，昭和 59.3。このほか, 入手した地 方公共団体の昭和 53 年, 58 年住宅需要実態調查結果報 告も同様である。

13）建設省住宅局：昭和 58 年・住宅需要実態調查結果報告 (統計表編)，p. 3，昭和 59.3。拡大調查を行った地方公 共団体ではこれより高い抽出率となっている。

14) 青森県, 神奈川県, 愛知県, 京都府, 福岡県, 大分県, 鹿児島県, 沖縄県。

15）青森県; 山形県, 福島県, 茨城県, 杤木県, 埼玉県, 東 京都, 神奈川県, 山梨県, 愛知県; 大阪府, 兵庫県, 高 知県, 福岡県, 大分県, 沖縄県。

16）「居住水準」(規模要因のみ）の状況は，住戸の規模と同 時にそこに住む世帯構成の状況によって異なる。住戸の 規模については，昭和 58 年住調結果によれば，昭和 45 年以前建築の公営住宅の延面積の分布状況は, ほかの住 宅利用形態 (持ち家，民営借家等）に比べ，特定のラン クに集中傾向がみられる(全国レベルで，30 -49 $\mathrm{m}^{2}$ の ランクに約 $80 \%$ が含まれている)。これは，公営住宅で は，従来から構造別に「一戸当たりの標準床面積」を設 定しており，このことが大きく影響していると思われる。 一方, 世帯構成については,「昭和 45 年以前建築の公営 住宅」という条件では，住調，住需調，国調等では集計 されておらず, 全国レベルの状況は把握し難い。したがっ て,ここでは昭和 58 年住調結果を使用し，住戸規模とそ こに居住する世帯構成の結合状洗である「居住水準」の 状況を, 全国レベルと, 福岡県レベルおよび北九州市, 福岡市を比較し，分析対象の位置付けを試みた。

17）「収入調查」は, 公営住宅法により, 毎年 1 回公営住宅に 引き続き約 2 年以上入居している世帯に対し実施される もので，入居世帯の収入のほか，調查時点における同居 者全員の氏名, 続柄, 生年月日等が調查されている。

18）管理主体によって,「入居者管理カード」,「請書」等呼称 が異なる。

19）昭和 51 年の第三期住宅建設五箅年計画で設定された「居 住水準」は，昭和 42 年 12 月の住宅対策箱議会の基本問 題部会による「適正な居住水準についての中間報告」を 理論的基礎にしているといわれている。また，その内容 を詳しく述べたものとして，「公団住宅住居基準の設定に 関する研究9)」があり，それによれば，「寝室」は，ふと んによる就寝を前提とし，寝窒内で個人の生活活動が可 能なように家具配置も考慮して, 部屋の広さが設定され ている。したがって， 3 畳と 4 畳半が隣接し，かつふす ま等で仕切られ，簡易に取りはずせ，一体として使用可 能である場合は（そのためには，1 間以上の開放が必要 と思われる) 2 空を合計し 7 睤半の居住室と認める判断 方法も考えられるが, 当平面 (図一4のA）住戸の場合 壁で仕切られており，2 室を合わせて 1 居住室とするに は使用上無理があると判断し，独立した 3 疊の部屋は考 虑していない。

20） 3 期計画設定の「最低水準」「平均水準」それそれれ，「住
戸規模の目標」の中で規定されている。

21）文 6)，pp.373 387, 昭和 46.4 。

22）今回対象の公営住宅に限らず，都市住宅では一般にみら れる傾向であり，民間分譲集合住宅（福岡市）について， これらに関する分析を第 2 報で触れる予定である。

23）「最低居住水準」設定では，12 歳以上 17 歳以下の子供 については性別就寝が条件であるが，同性の場合，同室 就寝が認められるため,この世帯構成の場合, 夫婦寝室 6 畳十子供寝室 ( 2 人) 6 畳 +4 畳半の DK で合計 16.5 畳以上の広さがあれば，「最低居住水準」を満たすことに なる。

24）まったく同一の構成比にならないのは，3期計画設定の 「居住水準」の内容には明記されていない，「夫婦」と同 室就蔓可能な未就学児が 2 人以上いる場合や, 片親と末 就学児の場合の寝室条件等の処理方法の違いによるもの と思われる。

25）「居住水準」の判定に住戸専有面積を加味した検討につい ては, 今回分析対象とした公営住宅を対象に行った結果 を第 2 報で触れる予定である。なお，従来の住調では併 用住宅の場合「住宅の延べ面樻」に営業に使用している 部分も含まれているが居住水準」の実態把握には，これ を居住用と営業用に区別して調查することが望まれる。

\section{主な参考文献・資料}

1) 住宅問題委員会：庶民住宅の技術的研究，建築雑誌， Vol. 55, No. 671, pp. 1 29, 昭和 16.2

2）西山外三・ほか：住宅設計基準と規格平面に就いて，建 築学会大会論文集, No. 25, pp. 126 133, 昭和 17.4

3）本城和彦：住居水準の国際比較, 住宅問題講座 1-現代 住居論・第 8 章，有斐閣，昭和 46.9

4) 住宅問題研究会：住宅問題, 相模書房, 昭和 26.11

5) 三輪 恒：住宅の規模分布（1）～( 5 ）, 日本建築学会論 文報告集, No.112, 115, 119, 120,124，昭和 40.6, 40.9， 41. $1,41.2,41.6$

6）丸山良仁編著：日本の住宅計画一新五箇年計画の解説一, 住宅新報社, 昭和 46.4

7）玉置伸俉・ほか：住宅数分布と世帯人員分布の対応に関 する考察及び世帯当り剩余室数分布の正規分布化，日本 建築学会論文報告集, No. 299, pp. 147 154, 昭和 56.1

8）渡辺光雄・ほか：住空間における家具占有面積の分析, その 1，2, 日本建築学会論文報告集, No. 352, pp. 48 58, No. 362 , pp. 103 112, 昭和 $60.6,61.4$

9）本城和彦・ほか：公団住宅住居基準の設定に関する研究, 住宅公団・調査研究報告集 14. pp. 45 80, 昭和 44 年

10）谷 重雄：住居水準と住宅政策, pp. 2 7, 住宅, Vol. 23, No. $5,1974.5$

11）住田昌二：居住水準のとらえかた一住宅・環境整備の戦 略概念として一pp. 8 13, 住宅, Vol. 23, No. 5, 1974.5

12）鈴木俊夫：居住水準設定の行政的役割について, pp. 14 ２0, 住宅, Vol. 23, No. 5, 1974.5

13）三宅 醇: 「狭小過密」指標の再検討, pp. 21 27, 住宅, Vol. 23, No. 5, 1974.5

14）厚生省生活局：昭和 16 年大都市住宅調查統計表

15）総理府, 総務仃: 昭和 23 年 $\sim 58$ 年住宅統計調查報告

16）建設省：昭和 35 年 $５ 8$ 年住宅需要実態調查結果報告

17）建設省住宅局住宅政策課監修：住宅宅地審議会答申集, 
日本住宅協会, 昭和 56.6

18）建設大臣官房広報室編集：日本の住宅と建築，建設広報 協議会，昭和 57.10

19）建設省住宅局：新たな居住水準の検討のための調查報告 書, 昭和 57.3

20）（財）日本住宅総合センター：居住水準の実態と予測に関 する調查, 昭和 57.7

21）日本建築学会建築経済委員会：これからの社会と住居水 準, 昭和 60.10

22）飯田利彦・ほか：「居住水準」判定の問題について, 福岡
大学工学集報, 第 31 号, 昭和 58.9

23）飯田利彦・ほか：「居住水準」判定の検討一公団住宅（九 州支社), 福岡県営住宅の場合一福岡大学総合研究所報,

第 86 号，昭和 60.10

24）飯田利彦・ほか：「居住水準」判定の問題について（その 3）福岡県営住宅 (初期) の場合, 日本建築学会大会学術 講演梗概集（計画系）pp. 575，576，昭和 60.10

25）小泉重信：住宅政策論, 新建築学大系 14 ・ハウジング・ 3 , 彰国社, 昭和 60.10

\section{SYNOPSIS}

UDC : 333.32

\section{ON THE VALUATION BY HOUSING STANDARD}

-At Municipal Rental Houses, constructed before 1969 in FUKUOKA Prefecture--

by TOSHIHIKO IIDA, Assist. of Fukuoka Univ. Member of A. I. J

The MINIMUM and ORDINARY HOUSING STANDARD-established 1976 in JAPAN-have four criteria, i.e ; 1) dwelling room (bedroom, dinning room, etc. ), 2) facilities (lavatory, etc), 3) dwelling environment and 4) size of dwelling by number of household members (number of rooms, size of dwelling rooms area of living quarters, total area of dwelling, etc. ).

There were essential differences between reports of the two national housing surveies in 1978, JAPAN. One of the differences is the level of HOUSING STANDARD, the results of surveies were inconsistent at many cities and prefectures.

In this issue I tried to analyze this difference by three cases of criteria combination at municipal rental houses, constructed before 1969 in Kitakyushu City 5,745 dwellings, in Fukuoka City 4,295 dwellings and in Fukuoka Prefecture 7,557 dwellings. Gathering and regulating these data on member and structure of households, plans of these municipal rental houses were proceeded during 1984-1986, by cooperation with students of Fukuoka University under municipal facilities and assistances. Three cases are following.

Case 1 ; criteria of 1) and 4), members and structure of household, plan of house,

Case 2 ; criteria of 1 ) and 4 ), members and structure of household, total members of TATAMI,

Case 3 ; criteria of 4 ), total members of TATAMI according to members of STANDARD HOUSEHOLD,

The result of analyzation shows that the ratio of households under the MINIMUM STANDARD by THE CASE 1 are $10 \sim 20 \%$ more than the same by THE CASE 2. Further the ratio of lst KIND rental hoseholds under MINIMUM STANDARD by THE CASE 2 are $5 \sim 6 \%$ less than the same by $\mathrm{T}_{1_{+}}^{-} \mathrm{E}$. CASE 3 at Fukuoka City and Fukuoka Prefecture municipal rental houses. But there are few differences at Kitakyushu City municipal rental houses.

To the contrary the ratio of 2 nd KIND under MINIMUM STANDARD by THE CASE 2 are $6 \sim 7 \%$ more than the same by THE CASE 3 generally. STANDARD HOUSEHOLD at THE CASE 3 negrects structure of household and it effected. cf, fig. -8 . 